\title{
ANALISIS E-BISNIS TERHADAP AMAZON DAN AQUARELLE
}

\author{
Evawaty Tanuar; Agustinna Yosanny \\ Jurusan Teknik Informatika, Fakultas Ilmu Komputer, Bina Nusantara University \\ Jln. K.H. Syahdan No. 9, Kemanggisan, Palmerah, Jakarta 11480 \\ etanuar@binus.edu
}

\begin{abstract}
The internet and digital world is one thing that needs to be taken into account by the Company. Business through Internet, known as e-business, is another way to increase the relation between company and customers or prospective customers. Analysis from the view point of customers and the integration of technologies was conducted on 2 examples sites that well known in doing online business but have different history on how it started the e-commerce. They are Amazon and Aquarelle. By comparing the two sites, the characteristics of e-commerce sites could be studied. As a result, there are striking differences between these two sites, where Amazon is more oriented to sales, while Aquarelle more on customer-oriented impact to the design and implementation of their e-business.
\end{abstract}

Keyword: e-business, Amazon, Aquarelle, online business.

\begin{abstract}
ABSTRAK
Perkembangan internet dan dunia digital sekarang menjadi salah satu hal yang perlu diperhitungkan oleh Perusahaan. Bisnis dengan memanfaatkan internet yang dikenal dengan e-bisnis ini, dan merupakan cara lain untuk mendekatkan perusahaan dengan pelanggan dan calon pelanggan. Analisis dari sudut pandang pelanggan dan pengintegrasian teknologi dilakukan pada 2 contoh situs yang telah terkenal dalam bisnis online tetapi memiliki latar belakang yang berbeda, yaitu Amazon dan Aquarelle. Dengan membandingkan kedua situs tersebut, karakteristik sebuah situs e-commerce yang baik dapat dipelajari. Hasilnya terdapat perbedaan yang mencolok antara kedua situs ini, dimana Amazon lebih berorientasi pada penjualan, sedangkan Aquarelle lebih berorientasi pada pelanggan berdampak pada cara mendesign dan mengimplementasikan aplikasi e-bisnis.
\end{abstract}

Kata kunci: e-bisnis, Amazon, Aquarelle, online business. 


\section{PENDAHULUAN}

Peranan internet dan kegiatan online sangat penting baik digunakan untuk publikasi informasi maupun transaksi bisnis untuk sebuah perusahaan. Hal ini sudah terbukti sangat berpengaruh dalam menunjang peningkatan pelayanan dan bisnis. Beberapa tahapan dan perkembangan online telah dirasakan dan dilalui, yaitu mulai dari kehadiran internet yang berguna untuk mendapatkan informasi secara online yang sederhana, e-commerce hingga e-bisnis. Menurut Berman (2000) "Lupakan B2B (Business to Business) ataupun B2C (Business to Customer), bisnis adalah mengenai P2P (Path to Profitability) - jalan menuju profitabilitas atau keuntungan".

Dalam hal ini, dapat dilihat trend yang jelas dan diikuti oleh banyak perusahaan, dengan mengintegrasikan atau mengabungkan bisnis dengan Web sebagai salah satu aktivitas komersial yang kini telah menjadi tantangan yang penting. Memang, jika dikelola dengan baik, aktifitas online dapat menyebabkan peningkatan keuntungan. Tetapi disisi lain, integrasi yang buruk dapat menyebabkan berbagai masalah yang dapat mengancam perusahaan.

Dalam rangka memberikan gambaran yang baik mengenai e-bisnis pada era digital ini, analisa kritis telah dilakukan pada dua perusahaan e-bisnis yang sukses, yaitu Amazon.com dan Aquarelle.com.

Amazon.com dimulai pada tahun 1994 oleh Jeff Bezos. Amazon merupakan salah satu perusahaan pertama yang menjual barang-barang (awalnya buku) melalui internet. Seiring perkembangannya, saat ini Amazon telah menyediakan berbagai jenis barang dan telah melebarkan sayapnya di kancah internasional dengan memiliki domain untuk kepeluan belanja online di berbagai negara.

Aquarelle.com didirikan pada tahun 1987 oleh François dan Henri de Maublanc. AQUArelle's tercipta pertama kali didorong oleh perkembangan Minitel ataupun cabang-cabang kecil di Prancis. Aquarelle adalah perusahaan yang menfokuskan dirinya pada penjualan bunga dan hadiah-hadiah yang berfungsi sebagai tambahan. Dimulai sebagai sebuah perusahaan yang telah stabil proses bisnisnya, tetapi mulai mencoba meningkatkan kualitas dan pelayanan kepada pelanggan dengan adanya tambahan pelayanan di Internet. Awalnya merupakan sebuah perusahaan di Eropa, dan mengembangkan konsep Minitel (cabang) di negara bagian Eropa. Sekarang ini telah melakukan expansi ke negara-negara di luar Eropa juga.

Kedua perusahaan yang dianggap merupakan pemain penting dalam e-bisnis dengan awal dan visi misi yang berbeda ini akan dianalisis secara detail berdasarkan dua perspektif. Kedua perspektif tersebut adalah perspektif dari sisi pelanggan (customer perspective) dan perspektif yang berfokus pada pengintegrasian teknologi (Integration of IT).

\section{HASIL DAN PEMBAHASAN}

\section{Sudut Pandang Pelanggan (Customer Perspective)}

Perspektif pelanggan adalah salah satu faktor paling penting yang perlu diidentifikasi ketika datang dan melihat ke perusahaan e-commerce yang telah berhasil. Penelitian telah menunjukkan bahwa jika sebuah situs web terlalu rumit atau sulit untuk digunakan oleh calon pelanggan, dapat mengakibatkan calon pelanggan tersebut menjadi bingung dan meninggalkan situs tersebut (Pearson, $\mathrm{J}$ dan A, \& Green, 2007). Hal ini sangat mudah dimengerti karena website adalah antarmuka (interface) 
pertama antara pembeli dan perusahaan. Sebelumnya pembeli menilai dan melihat produk sebuah perusahaan melalui jendela tampilan di toko, yang mana sekarang pada era digital, telah digantikan dengan melihat antramuka situs (web interface) dari sebuah perusahaan.

Waktu untuk bereksperimen dengan teknik-teknik baru terhadap internet pada era digital ini telah berakhir. Hal ini dikarenakan pengembangan e-commerce dari awal hingga saat ini telah berlangsung selama lebih dari 10 tahun. Hal ini menyebabkan pengembang website seharusnya menyadari tantangan baru yang melebihi sekedar teknik memanfaatkan sebuah situs. Tantangan tersebut adalah bagaimana memaksimalkan kegunaan dan interoperabilitas (usabilily and interoperability) dari sebuat situs.

\section{Halaman Utama (Interface) Amazon}

Amazon hadir di seluruh dunia dengan halaman awal amazon yang bervariasi, tergantung pada negara pengakses. Walaupun berbeda-beda tergantung negaranya masing-masing (terlihat dari domain situsnya) Amazon memiliki halaman awal yang khas dan klasik seperti pada Gambar 1 berikut ini.

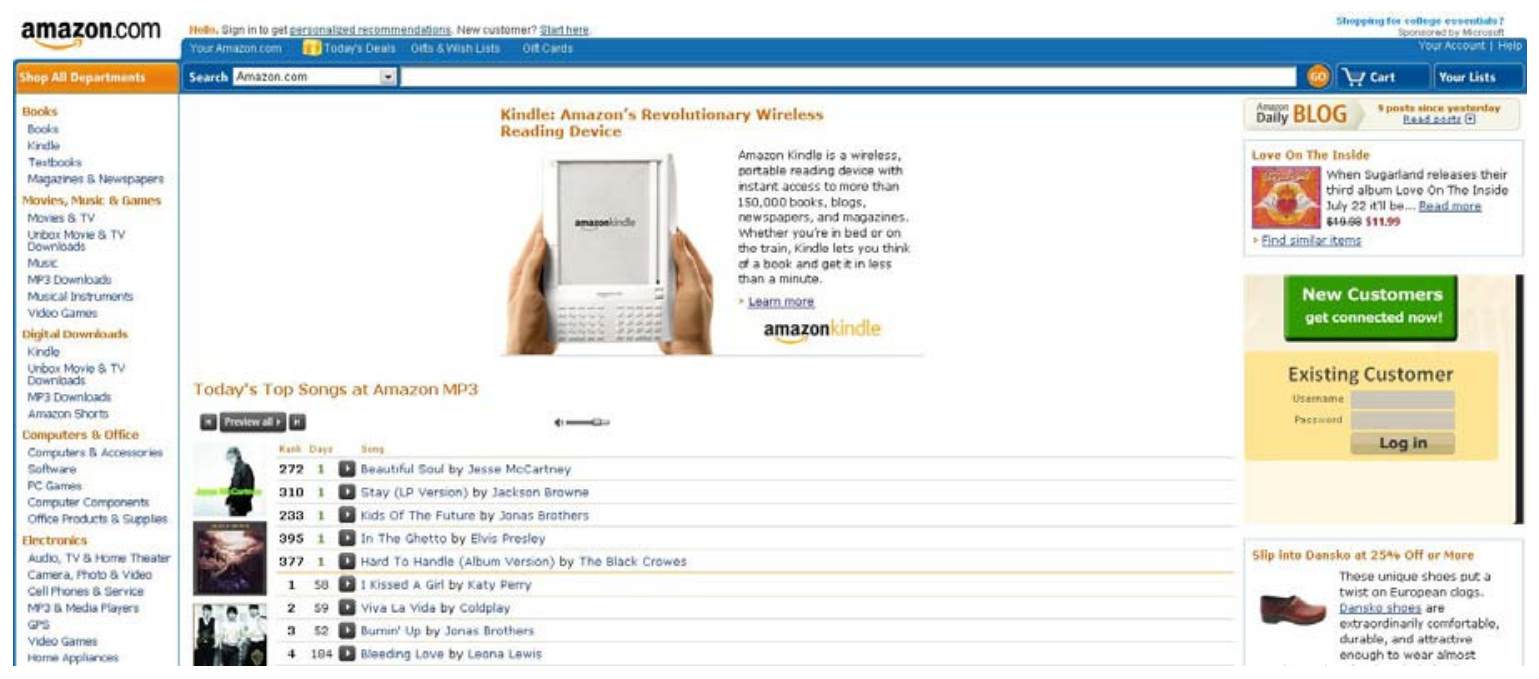

Gambar 1. Halaman Awal Amazon.com

Antarmuka (interface) situs amazon.com sangat klasik dan memiliki standar dengan fitur-fitur yang pasti seperti : (1) sebuah tempat pencarian (search bar) yang memungkinkan pengguna untuk mencari produk tertentu. Pencarian disediakan dalam bentu menu dropdown (menu pilihan yang tersusun kebawah), bertujuan untuk membatasi pencarian dalam konteks tertentu (Gremett, 2006). (2) sebuah menu di sebelah kiri yang dapat diakses setiap saat, untuk memindahkan halaman dengan cepat ke bagian-bagian yang berbeda dalam situs untuk mendapatkan informasi yang diinginkan. (3) Sebuah kotak di sisi kanan memungkinkan pelanggan untuk masuk ke dalam account (Your account). Hanya saja tombol ini terletak antara pengumuman-pengumuman yang cukup mengganggu.

Sebagai pembanding lainnya, terlihat halaman awal untuk amazon.fr, sangat konsistenlah seperti website utama amazon.com. 


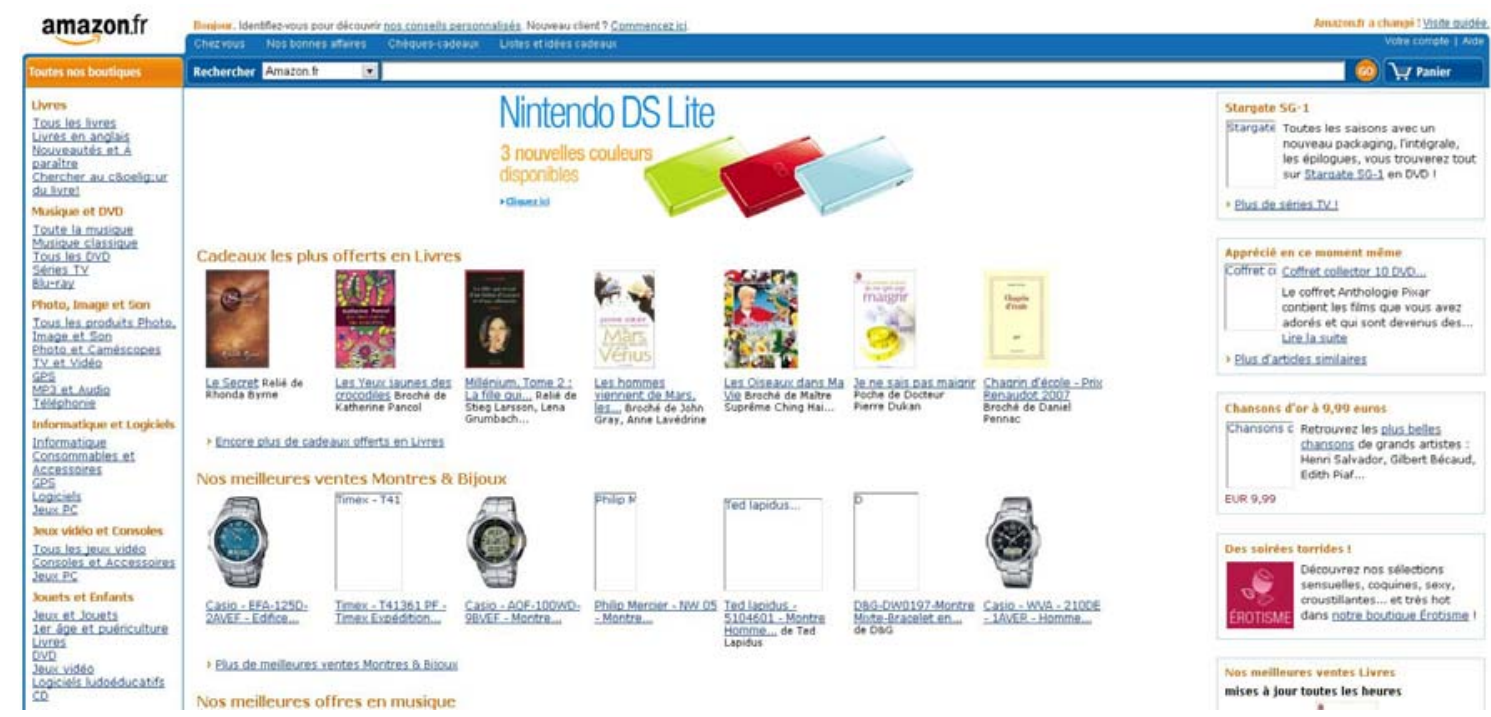

Gambar 2. Halaman Utama Amazon.fr

Memang, tampaknya amazon.fr merupakan terjemahan sederhana dari website utama di Amerika (Amazon.com). Namun sebenarnya lebih dari itu, karena ada fitur khusus yang hanya disertakan dalam versi Perancis. Antarmuka (interface) ini relatif baru yaitu dengan adanya panduan tutorial untuk pengguna. Tutorial ini berfungsi untuk menunjukkan dan menjelaskan kepada para calon pengguna yang kesulitan untuk mengetahui tentang bagaimana halaman ini bekerja. Hal ini ditunjukkan seperti pada gambar 3.

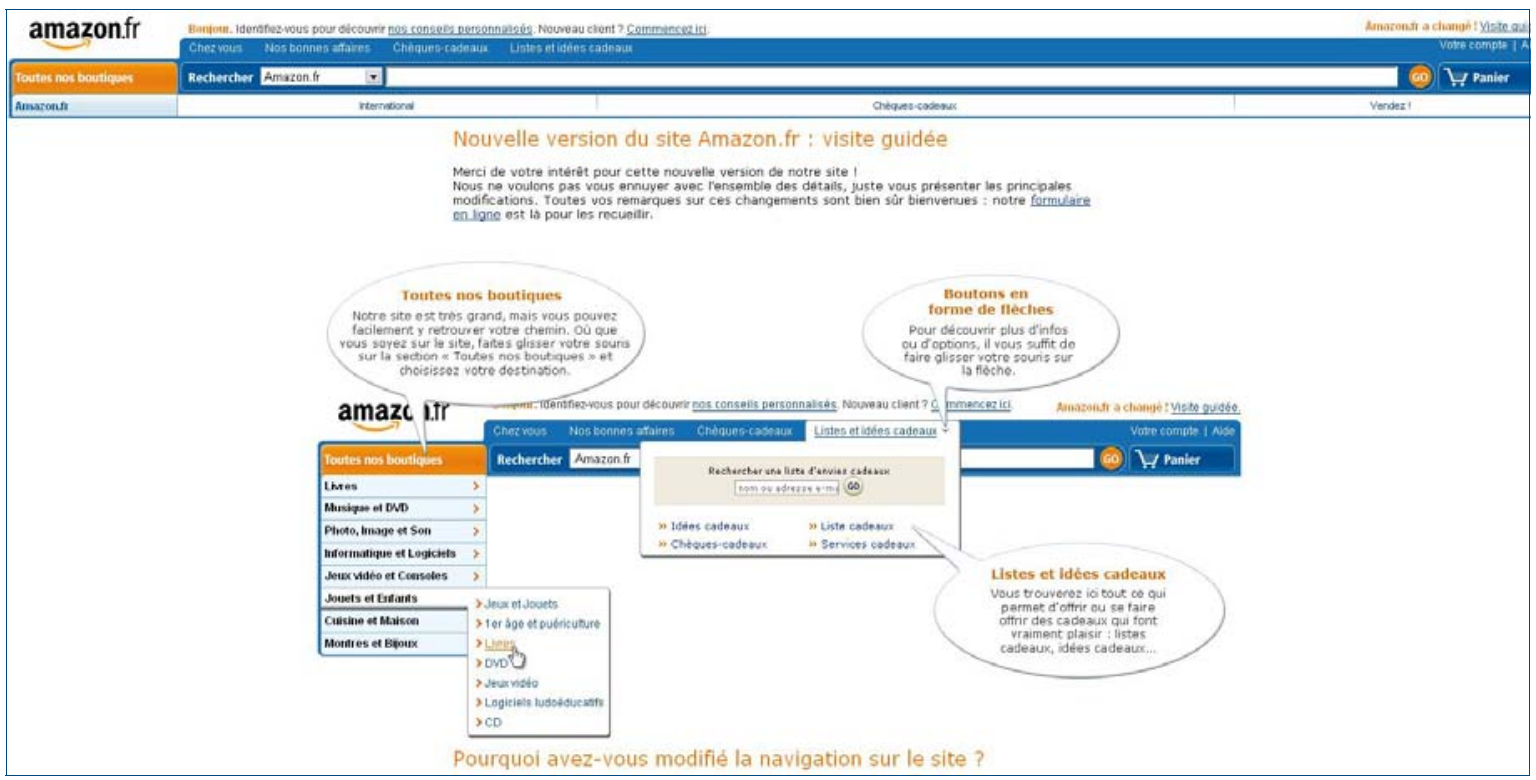

Gambar 3. Petunjuk (Guided Tour) pada versi Prancis

Halaman petunjuk pemanfaatan situs merupakan fitur yang hanya ada di Amazon Prancis. Hal ini ada karena Amazon Prancis menerapkan hasil survei yang dilakukan di seluruh dunia dan terutama di Perancis, dimana hasilnya, tutorial atau petunjuk bagaimana memanfaatkan internet itu penting dan berguna untuk meningkatkan tingkat kegunaan (usability). Hal ini menunjukkan bahwa ada beberapa 
jenis strategi tentang penggunaan web yang dibangun oleh Amazon sesuai dengan karakteristik penggunanya yang dilihat berdasarkan negara dan kebiasaan penduduk di negara tersebut.

Kejadian pada situs Kanada, dimana pada situs ini terdiri dari dua bahasa yang spesifik sangatlah unik. Hal ini disebabkan karena peluncuran Amazon di Kanada sangat kontroversial. Karena adanya pembatasan dan peraturan di Kanada mengenai proses penjualan buku jalur internasional sedang berlaku.

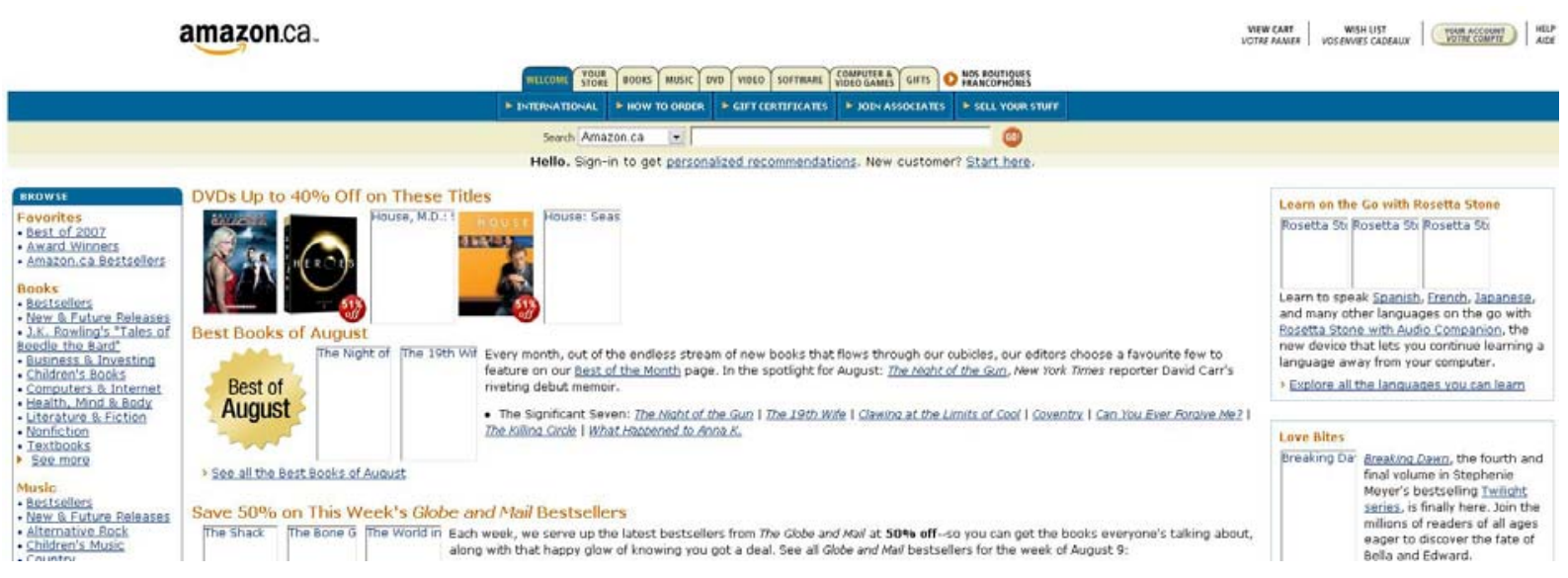

Gambar 4. Halaman Awal Amazon.ca

Ketika melihat antarmuka (interface) pada situs Kanada ini, ada beberapa perbedaan dengan amazon.com yang bisa kita amati, yaitu warna pada halaman ini sedikit berbeda dengan amazon.com. Menu pilihan (tabulation) dibuat agar dapat terlihat dengan jelas, tidak seperti pada amazon.com. Dan yang terakhir, seperti pada versi Prancis, menu untuk registrasi berada pada pojok kanan atas, dimana tidak terganggu oleh berbagai pengumuman dan iklan.

Antarmuka ini sangatlah berbeda (inconsistent) bila dibandingkan dengan antarmuka pada situs international, amazon.com. Walaupun Amazon di masing-masing negara memiliki sedikit perbedaan dengan Amazon pusat, tetapi bila dilihat secara sekilas, karakteristik Amazon sangatlah terlihat. Pengguna pasti akan mengetahui bahwa sebuah situs adalah situs Amazon walaupun tidak sepenuhnya mirip dengan Amazon pusat.

\section{Halaman Utama (Interface) Aquarelle}

Pada situs yang berbeda Aquarelle memilih tampilan yang polos, jernih dan sederhana sebagai jendala tampilan (Showcase window). Warna yang dipilih sebagai karakteristik dari situs ini juga sangat konsisten. 


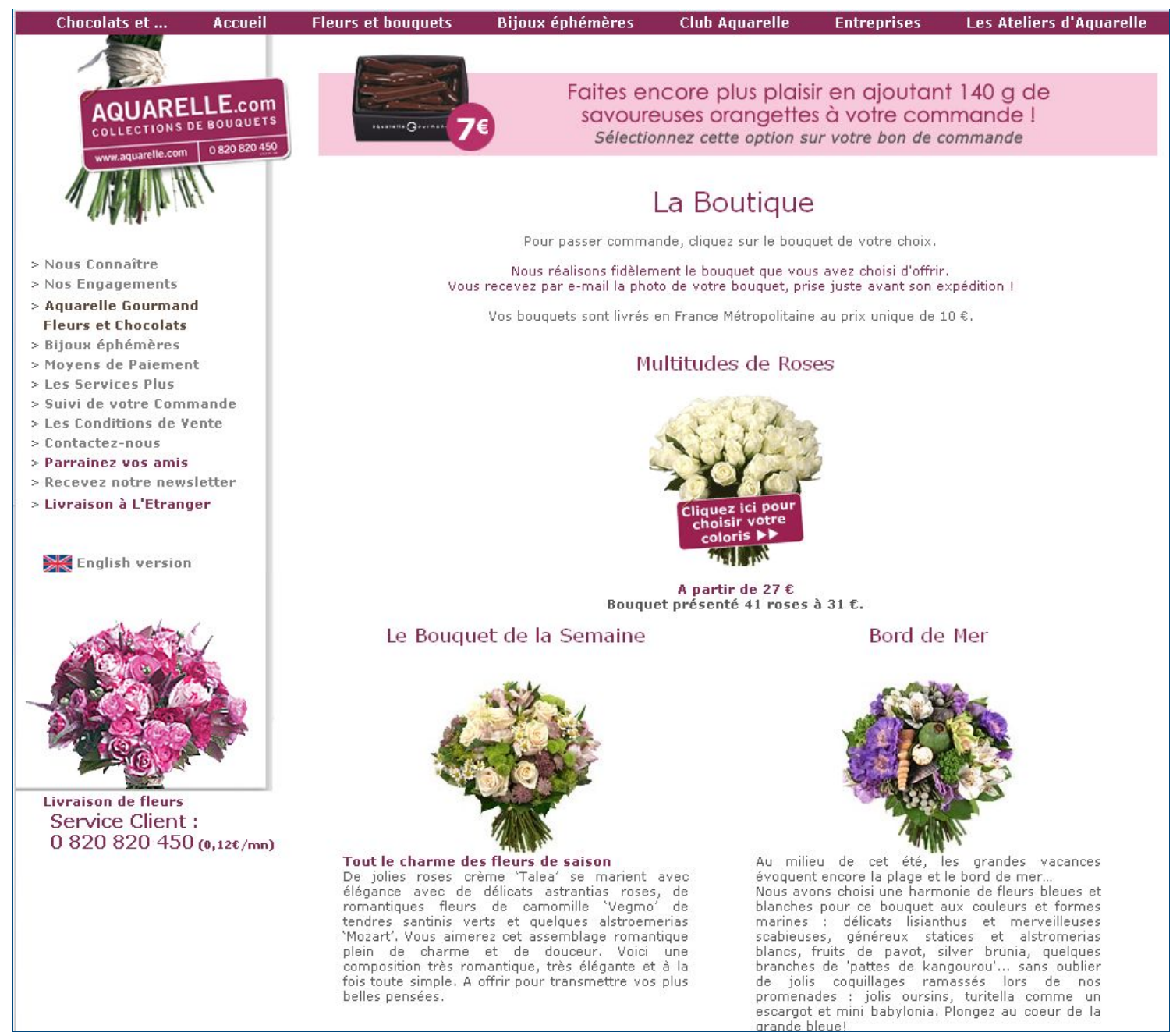

Gambar 5. Halaman Awal Aquarelle.com

Sekali lagi, sebuah menu di sebelah kiri dan tabulasi di atas bertujuan agar dapat langsung dilihat oleh pengunjung. Katalog dapat diakses langsung dari halaman awal. Tidak ada bar pencarian (search bar) yang dapat ditemukan, tetapi disisi lain nomor telepon sangat terlihat di bagian bawah sebelah kiri. Nomor telepon yang terlihat jelas ini juga merupakan salah satu strategi dimana Aquarelle masih melakukan dan berfokus pada bisnis proses yang tradisional. Harapannya adalah pelanggan ataupun calon pelanggan dapat mencatat dan menelepon Aquarelle untuk melakukan pemesanan dimana hal itu masih dirasa lebih mudah daripada pemesanan secara online.

Perpindahan antar bahasa yang berbeda dan nama domain seperti aquarelle.co.uk, tidak mempengaruhi antarmuka karena hal ini murni hanya merupakan sebuah terjemahan dari halaman utama situs Prancis. Selanjutnya, adanya integritas yang erat terhadap situs-situs aquarelle.com. Aquarelle memberikan pelayanan berupa kemungkinan untuk memesan tanpa mendaftar. Hal ini sering dihargai oleh pelanggan yang tidak ingin memasukkan informasi pribadi atau hanya ingin transaksi tanpa menjadi pelanggan.

Aquarelle juga pastinya memberikan pelayanan berupa kesempatan untuk mendaftar sebagai pelanggan tetap. Tetapi bila pelanggan mengakses dari situs yang berbeda, maka informasi pribadinya (alamat, email, telepon, dll) tidak perlu ditulis kembali karena telah tercatat dan sama dengan informasi dimana pelanggan pertama kali mendaftar. Dengan kata lain sebuah informasi pelanggan di satu situs, juga tercatat di situs Aquarelle lainnya. 
Disamping itu, formulir pendaftaran di sini jugalah sangat sederhana dan mudah sepert gambar di bawah ini:

\section{Yos Coordonnées}

Elle seront pré-saisies lors de vos commandes passées avec votre carte

\section{* Champs obligatoires}

Titulaire

Nom

Prénom

Téléphone

E-mail
CMme $C$ Mlle 6 M C Mme et M

\section{BARAT}

Vincent *

$\longdiv { 0 4 3 2 3 1 6 5 2 5 } *$

aquarelle@barat.name

Choisissez un mot de passe d'au moins 4 caractères (Lettres ou chiffres)

Mot de passe

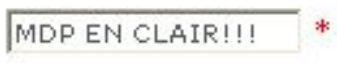

Confirmation

PAS BON DU TOUT $*$

Gambar 6. Form pendaftaran pelanggan

Walaupun terlihat sederhana seperti pada Gambar 6, tetapi ada beberapa kelemahan, dimana hal ini sangat krusial dan bertentangan dengan aturan keamanan standart. Kelemahannya antara lain: password yang diketik terlihat jelas (tidak disembunyikan atau diganti dengan *), password tidak case-sensitive, dan email konfirmasi dikirim ke pengguna dengan password yang terlihat dengan jelas. (Gambar 7)

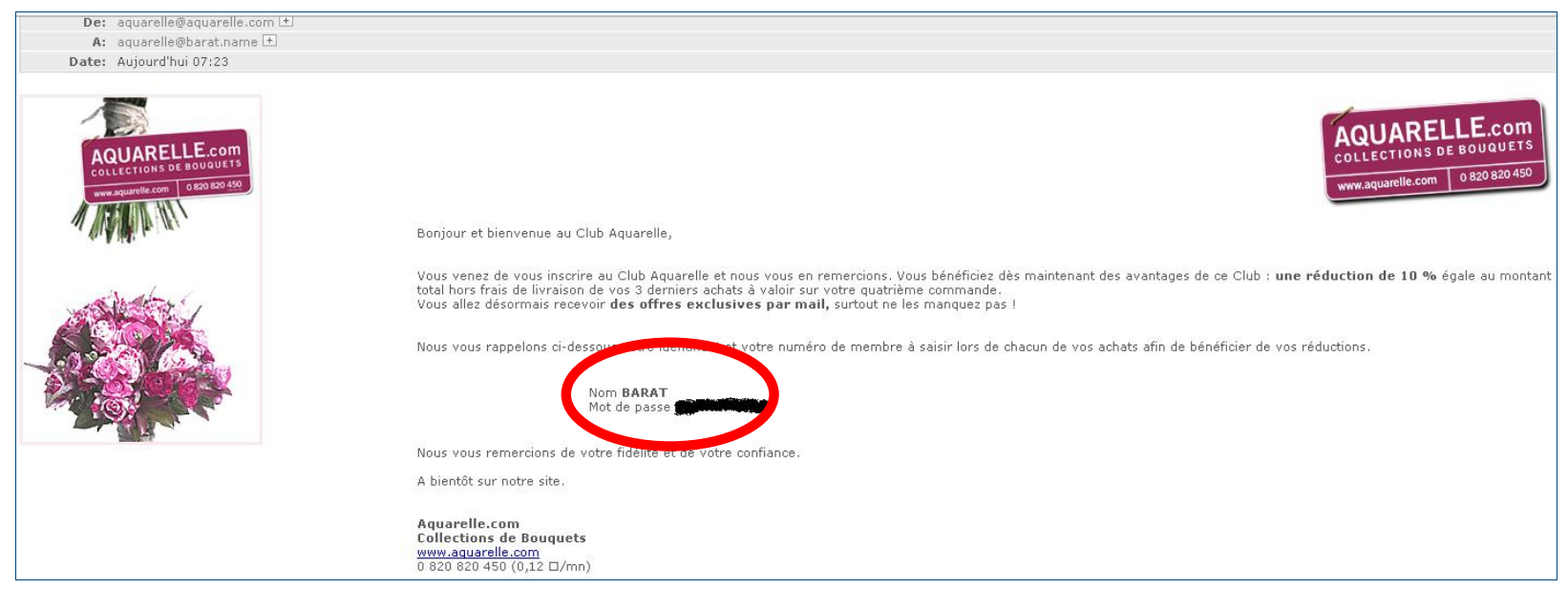

Gambar 7. Email konfirmasi 


\section{Penggunaan website (accessing the website)}

Berfokus pada kemudahan penggunaan, Aquarelle dengan tampilan yang sangat sederhana lebih efisien dibandingkan dengan Amazon. Kenyataannya situs Amazon sangat padat dan berisi banyak informasi dan iklan. Meskipun Aquarelle menggunakan konsep yang tampak tua dan sederhana, namun terlihat langsung tertuju pada tujuan utamanya, yaitu informasi produk perusahannya. Dari kedua situs web ini, dapat dilihat bahwa kedua situs tidak menggunakan konten dinamis yang terlalu banyak dimana dapat membingungkan pelanggan.

Pada Amazon, tujuan dari sign in - masuk sebagai pelanggan tercatat sangatlah jelas, yaitu untuk mendapatkan rekomendasi sesuai dengan produk pada hari tersebut. Situs web "mengingat" selera dan produk yang pernah dibeli sebelumnya dan akibatnya dapat menawarkan produk yang dirasa mungkin menarik bagi pelanggan, dengan tujuan meningkatkan penjualan.

Dalam kasus Aquarelle, tidak ada customization - pilihan dan rekomendasi yang benar-benar disediakan untuk pelanggan. Dalam situs ini, yang tersedia hanyalah sebuah potongan sebesar 5\% yang secara otomatis didapatkan oleh semua pelanggan. Walaupun demikian, menurut Pearson dan Green (2007), kustomisasi bukan merupakan kriteria yang penting dan sepenuhnya bernilai bila dilihat dari sisi pelanggan.

Walaupun Amazon memiliki customization sebagai salah satu kelebihannya, tetapi seseorang yang telah melakukan registrasi pada situs yang satu, tidak dikenali pada situs yang lainnya. Memiliki account di amazon.ca bukan berarti pelanggan juga telah memiliki account pada amazon.cn. Ini adalah sesuatu yang berlawanan dengan Aquarelle, dimana dengan satu kali melakukan registrasi, dapat dimanfaatkan di berbagai situs aquarelle lainnya.

\section{Pengintegrasian Teknologi (Integration Of Technology)}

Sejak awal, Amazon dibangun dengan berorientasi pada teknologi dan internet. Berbeda dengan Aquarelle yang telah ada sebelumnya, Amazon dirancang dengan model bisnis yang unik tetapi sepertinya bisnis ini menunjukkan pertumbuhan yang lambat karena perusahaan itu akhirnya berhasil menghasilkan profit setelah 5 tahun. Hal Ini adalah salah satu alasan yang menjelaskan bagaimana Amazon bertahan dalam perubahan era bisnis dengan memanfaatkan internet (Internet Bubble burst) dan menjadi \# 1 dalam industrinya.

Amazon telah hadir di seluruh dunia dan memiliki cabang pengembangan perangkat lunaknya di Amerika Serikat, Inggris, Irlandia, Rumania, Cina, India, Afrika Selatan dan gudang di AS, di Perancis, Irlandia, Skotlandia, Inggris, India, Cina, Jepang dan Jerman.

Model bisnis global perlu diperkuat dengan integrasi yang sangat baik terutama yang tidak terlihat oleh pelanggan dan hanya dapat dirasakan (backend integration). Oleh karena itu, akan menjadi sangat baik bila pengguna dari Perancis yang ingin melakukan pemesanan di Kanada tidak perlu memberikan informasi pribadi lagi.

Pengujian juga dilakukan untuk mengetahui bagaimana pengorganisasian di Amazon. Hasilnya adalah tidak peduli dari mana asal negara seseorang, setiap pelanggan tercatat sebgai suatu individu yang unik pada database amazon. Namun, apakah mungkin untuk membicarakan integrasi keseluruhan (Big Integration) seperti yang didefinisikan oleh Gulledge (2006) pada situs Amazon?

Amazon sebenarnya adalah campuran antara "Big I and Small I", maksudnya adalah kelompok suatu negara menjadi suatu Big I (saya yang dalam ruang lingkup besar) dan identitas pelanggan sebagai Small I (saya secara pribada atau kecil). Hal yang membuat Amazon menjadi begitu unik adalah katalog dan backend yang sepenuhnya dapat diakses oleh siapa saja, berkat penggunaan Layanan Web. Amazon juga menciptakan Amazon AWS (Amazon Web Services) dan menyediakan sarana untuk pengembang aplikasi internet (web developer) untuk memasukkan fitur 
Amazon di situs webnya. Dengan adanya gagasan ini tidak hanya mengontrol Amazon secara vertikal (perusahaan dengan pelanggannya), tetapi juga memperluas hubungan secara horisontal melalui sesama pengguna internet. Dimana gagasan ini termasuk melampaui gagasan Porterian klasik dalam hal integrasi teknologi terhadap keuntungan bisnis.

Konsep ini sebenarnya cukup sederhana, yaitu situs web apapun dapat menjadi sebuah situs afiliasi dan menggunakan AWS itu, menulis ulang dan mendesain ulang fitur yang ada pada situs asli Amazon. Satu-satunya syarat adalah bahwa proses ini harus dilakukan melalui backend Amazon. Dengan membuka struktur informasi teknologinya untuk semua orang, Amazon mendapatkan peningkatan pendapatan dan menjadi landasan dasar pengaturan untuk perusahaan bisnis maya (model Enterprise Virtual). Proses pembelian sebuah buku dari sebuah situs afiliasi melibatkan begitu banyak pemain di dunia maya lainnya, sehingga kegiatan ini bisa disebut hypermediation (Luftman, 2003).

Situasi ini sangat khas, yaitu sebelum fenomena dot.com, Aquarelle telah menjadi pengusaha yang terkenal dengan mail order (pemesanan melalui surat). Sedikit dan perlahan-lahan pindah ke internet, sekaligus menjaga bisnis dengan model lama. Situasi yang luar biasa ini memungkinkan Aquarelle untuk bertahan dengan industrinya. Proses pemesanan pada Aquarelle dapat digambarkan seperti pada Gambar 8.

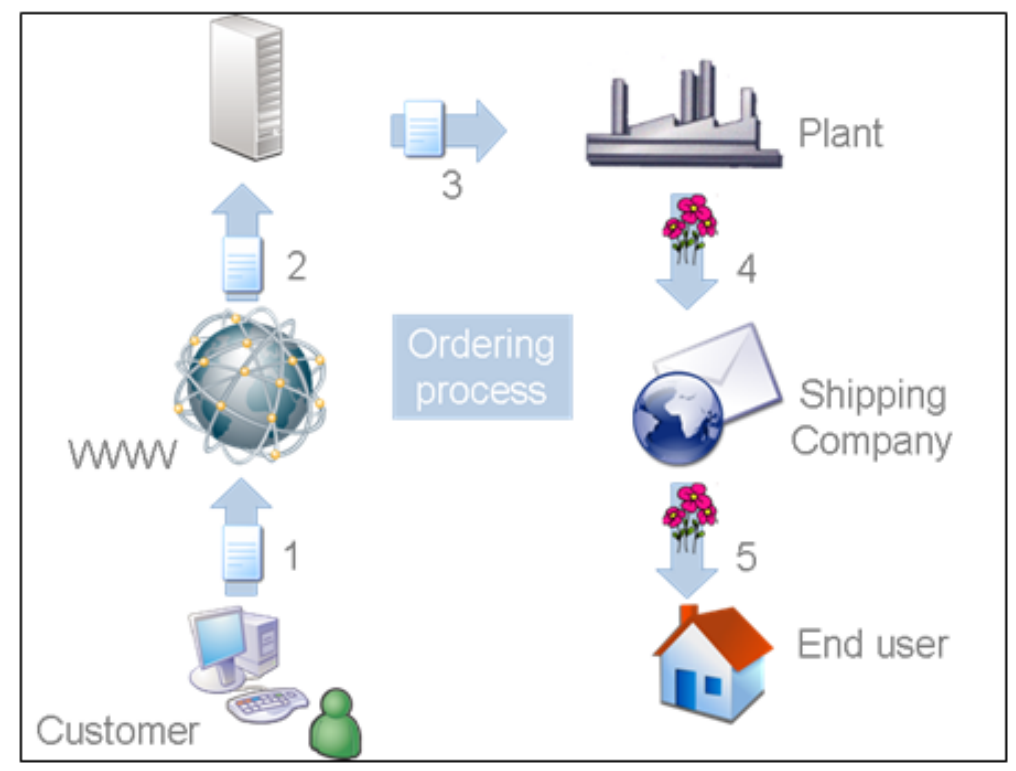

Gambar 8. Proses Pemesanan pada Aquarelle

Proses bisnis Aquarelle dimulai dengan pemesanan oleh pelanggan, yang dapat diakses melalui internet dan telepon. Informasi pemesanan dikirim ke cabang terdekat, lalu disiapkan barang yang telah dipesan, dilanjutkan dengan menghubungi perusahaan jasa pengiriman untuk mengantarkan barang tersebut kepada pelanggan.

Bagi Aquarelle pemanfaatan internet bukan merupakan tujuan utama mereka. Pemanfaatan internet ini hanyalah sebuah nilai tambah dimana dengan adanya informasi produk, pelanggan dan calon pelanggan dapat mempertimbangkan produk berupa bouquet yang akan dibeli. Tetapi seiring dengan perkembangan jaman dan pemanfaatan teknologi internet, Aquarelle mulai kembali mempertimbangkan pemanfaatan teknologi mereka, dan perlu merencanakan investasi yang lebih baik lagi. 


\section{SIMPULAN}

Dalam hal perspektif dan sudut pandang pelanggan, Amazon dan Aquarelle memiliki dua strategi yang sangat berbeda. Amazon menempatkan diri dengan penekanan pada review kustomisasi dan penjualan produk pada pelanggan. Di sisi lain, Aquarelle lebih memfokuskan pada kejelasan dan kemudahan pengguna untuk memperoleh informasi.

Amazon yang berorientasi pada penjualan produk dengan memberikan layanan berupa kustomisasi produk kepada pelanggannya mengakibatkan situs tersebut menyediakan informasi yang sangat banyak dan luas. Hal ini dapat menyebabkan pelanggan mengalami kelebihan informasi (overloaded information) yang mungkin juga berdampak pada pengunjung yang tidak lagi kembali untuk melakukan pembelian.

Aquarelle yang sangat sederhana dan nyaman dalam menyediakan informasi untuk pengunjung merupakan suatu nilai tambah. Hanya saja proses registrasi pelanggan pada situs ini perlu lebih ditingkatkan untuk menjaga keamanan data penting dari pelanggan.

Dari sudut pandang pemanfaatan teknologi informasi, ada dua kesimpulan yang dihasilkan dari berbegai analisa dan percobaan sebelumnya. Pertama, dengan melihat dari sejarah awal Amazon, mengakibatkan situs penjualan ini benar-benar terintegrasi di seluruh dunia. Pembukaan infrastruktur sistem informasi Amazon melalui penciptaan Amazon Web Services memungkinkan Amazon untuk menghasilkan ratusan website afiliasi yang pada akhirnya memberikan kontribusi terhadap pendapatan Amazon. Kedua, Aquarelle lebih efisien dan berorientasi memberikan informasi kepada kepuasan pelanggan. Teknologi yang backend yang cukup mahal membuat Aquarelle lebih memilih untuk melakukan proses bisnis campuran dimana setengahnya masih dijalanan dengan proses tradisional.

Meskipun kedua perusahaan telah terbukti sukses, tetap ada ruang untuk perbaikan terutama untuk Aquarelle. Namun, untuk menjadi pemain utama dalam era digital sekarang ini, usaha yang dilakukan masih perlu ditingkatkan lagi, secara banyaknya kompetitior yang mulai bermunculan. Dengan mengembangkan perangkat lunak CRM- nya, reputasi Amazon meningkat pesat, dan juga faktanya membuat Amazon menjadi lebih dekat kepada calon pelanggannya. Dalam konteks ini, Aquarelle benar-benar harus meningkatkan kompetensi manajemen pelanggan dan pemanfaatan teknologi.

Analisa dua situs terkenal di dunia online yang dilihat dari sisi tujuan dan asal muasal perusahaan menggunakan internet berdampak pada bagaimana suatu aplikasi e-bisnis di desain. Analisa lebih lanjut, dapat dilakukan terhadap situs online sejenis ini juga sesuai dengan negara asalnya sehingga bisa dilihat dan dianalisa karakteristik e-bisnis apakah juga dipengaruhi oleh lokasi dan kebiasaan pengguna di negara tersebut.

\section{DAFTAR PUSTAKA}

Berman, D.K. (2000). Dot Coms: Can They Climb Back?, Business Week online, June $26^{\text {th }}$

Foley, J., \& Konicki, S. (2000). Amazon's IT Agenda, Information Week, http://www.informationweek.com/811/amazon.htm

Gremett, P. (2006). Utilizing a User's Context to Improve Search Results, Journal of the American Society for Information Science and Technology, vol 57, no 6, pp808-812 
Gulledge, T. (2006) What is integration, Industrial Management \& Data Systems, Vol. 106 No. 1, 2006 pp. 5-20

Ives, B., \& Learmonth, G. (1984). The information system as a competitive weapon, Commun ACM iss.27, vol.12, pp1193-1201.

Luftman, J. (2004). Managing the Information Technology Resource: Leadership in the Information Age, Pearson Education

Pearson, J. M., Pearson, A., \& Green, D. (2007). Determining the importance of key criteria in web usability, Management Research News, Vol. 30, No. 11, pp. 816-828. 